\title{
Biodiesel and Other Value-Added Products from Bio-Oil Obtained from Agrifood Waste
}

\author{
Francisco José Sánchez-Borrego *, Paloma Álvarez-Mateos (D) and Juan F. García-Martín *(D) \\ Departamento de Ingeniería Química, Facultad de Química, Universidad de Sevilla, C/Profesor García González, \\ 1,41012 Seville, Spain; palvarez@us.es \\ * Correspondence: frasanbor@alum.us.es (F.J.S.-B.); jfgarmar@us.es (J.F.G.-M.); Tel.: +34-954-557-183 (F.J.S.-B.)
}

\begin{abstract}
Bio-oil is a promising source of chemicals and renewable fuels. As the liquid phase obtained from the pyrolysis of biomass, the composition and amount of bio-oil generated depend not only on the type of the biomass but also on the conditions under which pyrolysis is performed. Most fossil fuels can be replaced by bio-oil-derived products. Thus, bio-oil can be used directly or co-fed along with fossil fuels in boilers, transformed into fuel for car engines by hydrodeoxygenation or even used as a more suitable source for $\mathrm{H}_{2}$ production than biomass. On the other hand, due to its rich composition in compounds resulting from the pyrolysis of cellulose, hemicellulose and lignin, bio-oil co-acts as a source of various value-added chemicals such as aromatic compounds. This review presents an overview of the potential applications of bio-oils and the pyrolysis conditions under which they are obtained. Then, different extraction methods for value-added chemicals, along with the most recent developments, are discussed and future research directions for bio-oil upgrades are highlighted.
\end{abstract}

Keywords: biofuels; bio-oil; bioplastic; hydrodeoxygenation: pyrolysis; renewable fuel; recyclable plastics

Citation: Sánchez-Borrego, F.J.;

Álvarez-Mateos, P.; García-Martín, J.F. Biodiesel and Other Value-Added Products from Bio-Oil Obtained from Agrifood Waste. Processes 2021, 9, 797. https://doi.org/10.3390/pr9050797

Academic Editor:

Elsayed Elbeshbishy

Received: 30 March 2021

Accepted: 28 April 2021

Published: 30 April 2021

Publisher's Note: MDPI stays neutral with regard to jurisdictional claims in published maps and institutional affiliations.

Copyright: (C) 2021 by the authors. Licensee MDPI, Basel, Switzerland. This article is an open access article distributed under the terms and conditions of the Creative Commons Attribution (CC BY) license (https:// creativecommons.org/licenses/by/ $4.0 /)$.

\section{Biofuels: The Search for Alternative Fuels for Transportation}

Fossil fuels are still the main energy source worldwide; their overexploitation is resulting in their depletion and increases in global warming [1]. With the increase in energy demand, the price of fossil fuels is also increasing, as their supply is dominated by a few Middle Eastern countries. According to the International Energy Agency report, the energy demand in Asia (the most populated continent) will increase by $76 \%$ by 2030 [1].

Dependence on imported fossil fuels thus poses a serious threat to the energy security and economic stability of all countries as the world is expected to run out of petroleum in the next 50 years [1]. Due to these limited reserves of conventional fossil fuels and their negative impact on global climate and human health, much research is focused on the search for alternative energy sources. Along with other energy resources, such as solar, wind, hydroelectric, and nuclear energy, biodiesel can help reduce fossil fuel dependence. Biodiesel is a non-toxic renewable energy source that is gaining attention globally due to its direct applicability in preexisting engines without any modification, since its properties are similar to those of conventional diesel fuel.

Biodiesel is a renewable biofuel free of sulphur and polycyclic aromatic compounds, which are major advantages. Brazil, USA, Malaysia, Argentina, Spain, Belgium and Germany are among the top producers, meeting $80 \%$ of the biodiesel demand [1]. Blending, thermal cracking, micro-emulsification and transesterification are four basic approaches for production of biodiesel [2-4]. Among them, transesterification is the most commonly used method at the industrial scale due to less expensive operation and high product yield.

The availability of various oil resources (edible, non-edible and waste cooking oils) has been discussed elsewhere [1], along with the advancements in technology related to oil extraction. Palm oil and waste cooking oils are the main raw materials used nowadays for biodiesel production. Jatropha curcas oil (non-edible oil) is also regarded as a potential 
alternative to these raw materials [5]. Despite some drawbacks, such as poorer oxidation stability due to the high amount of unsaturated fatty acids, the high availability of oxygen in jatropha biodiesel reduces hydrocarbons, $\mathrm{CO}$ and particulate matter emissions. The comprehensive assessment of the performance and emissions of compression ignition engines operated on jatropha biodiesel and its blends can be found elsewhere [2,5]. On the other hand, the lower calorific value of jatropha biodiesel is responsible for a decrease in brake thermal efficiency and an increase in brake specific fuel consumption [2].

Various technologies, from the laboratory scale to industrial production, have been developed and many facilities have been established for biodiesel production using various feedstocks [1]. Thus, various innovative process intensification technologies (biological reactors, microreactors, membrane reactors, oscillatory flow reactors, microwave reactors, reactive distillation, centrifugal contractors, etc.) can be found in the literature [6-10]. On the other hand, the use of bio-based technologies in biodiesel production is regarded as advantageous as these methods generate less waste and are considered ecofriendly. To be specific, bio-based methods, such as those using immobilized enzymes and heterogeneous catalysts derived from biomass, have been reported to efficiently catalyze the transesterification reaction for biodiesel production [11,12]. The use of bio-oils as a source of biodiesel is still in its infancy. Nevertheless, it could represent a potential alternative for lignocellulose residues without any current feasible application.

\section{Agrifood Industry Waste}

Forestry and agricultural residues represent the typical lignocellulose raw material, these being the most plentiful sources of biomass in the world, generating around 200 billion tons per year [13]. For this reason, it is essential to develop new technologies to treat this biomass; otherwise, its accumulation as waste would affect the environment. Production of biofuels has already reached commercial scale. However, the industrial production costs of those biofuels, such as bioethanol, are still high, so they have to be cut down. Wood and straw were widely used as household fuels until charcoal began to replace wood from the beginning of the 20th century. Currently, the typical uses of lignocellulose at the commercial scale are syngas production by gasification and electricity generation.

In the last few decades, the use of lignocellulose biomass as a raw material for energy production, as well for materials for energy storage, has gained interest among researchers. Another important reason for the use of biomass is based on its renewability together with the reduction of the net carbon dioxide emission and wide distribution and availability. The major chemical components of lignocellulose biomass are cellulose, hemicelluloses and lignin. All of them have shown great potential as raw materials for energy generation [14]. For instance, cellulose can be described as a long-chain homopolymer consisting of D-glucose units with cellobiose as a repeating unit. Therefore, cellulose which can be fermented into bioethanol $[15,16]$ plays the main role in the production of biofuels from biomass.

A huge variety of enforcements have been implemented for functional materials derived from lignocellulose [17]. Hemicelluloses are known to be a group of polysaccharides consisting of short-branched chains. Hemicelluloses are also essential for the production of biofuels because they can represent up to $35 \%$ of the weight of biomass on a dry basis [14]. To be specific, the production of bioethanol from hemicellulose-rich biomasses, such as olive stones and olive tree-pruning residues, requires the use of non-conventional yeasts capable of fermenting not only D-glucose, but also pentoses (mainly D-xylose) $[14,15,18]$. Lignin has received less attention than the other lignocellulose constituents in biofuels production due to its composition, which is mainly based on aromatic compounds. Nevertheless, the modifications assayed in recent years to alter lignin structure have increased the interest in producing carbon materials for super capacitors or energy-storage materials from lignin [19].

Thermochemical conversion is a very important method when converting biomass into energy and fuels. Thermochemical conversion could be defined as the controlled 
heating or oxidation of raw materials, generating heat and energy products. This includes a wide range of techniques, including pyrolysis, liquefaction, gasification and combustion. Among all the thermochemical conversion techniques, the differences among them are based on their oxidation range and temperature [14,20].

Pyrolysis is a process of thermal decomposition of biomass that is carried out in the absence of oxygen, using instead inert atmospheres (e.g., argon or nitrogen). It is an endothermic process, so the products generated through this process have high energy content. The products generated in the pyrolysis are very heterogeneous and are mainly composed of volatile products (synthesis gas or syngas), a liquid fraction (bio-oil) and a solid carbonized waste (biochar). In turn, syngas consists of a mixture of $\mathrm{CO}$ and $\mathrm{H}_{2}$ (along with other compounds such as $\mathrm{CO}_{2}, \mathrm{CH}_{4}, \mathrm{C}_{2} \mathrm{H}_{6}, \mathrm{C}_{2} \mathrm{H}_{4}$ and $\mathrm{H}_{2} \mathrm{O}$ ) [14].

Another thermal pretreatment is torrefaction, which is characterized by being carried out at a low temperature $\left(200-300^{\circ} \mathrm{C}\right)$ and is designed to remove water and other volatile compounds [14]. With this procedure, a solid product is obtained with a lower oxygen content and a higher energy density than the original raw material. Torrefaction begins when the temperature reaches $200^{\circ} \mathrm{C}$, and ends when the temperature drops below $200^{\circ} \mathrm{C}$, utilizing a very short heating time. It could be considered a softer version of pyrolysis, as well as being less destructive structurally as a carbonization method [21]. The main gases produced by gasification are $\mathrm{CO}, \mathrm{H}_{2}, \mathrm{CH}_{4}$ and $\mathrm{CO}_{2}$. Compared to pyrolysis, the final products obtained from torrefaction require less post-treatment to use them.

When the process is carried out under air, which is a reactive atmosphere, complete gasification occurs at higher temperatures $\left(500^{\circ} \mathrm{C}\right)$, resulting in the formation of gaseous fuel and a solid residue (ash). High temperatures inhibit the formation and condensation of liquid products [22]. Gasification is composed of three steps. The first is called drying and it takes place at temperatures up to $120^{\circ} \mathrm{C}$. In this step, all the moisture from the raw material is removed to produce steam. The second step is called devolatilization and it occurs at temperatures up to $350{ }^{\circ} \mathrm{C}$ : the volatile matter from the raw material is lost, leading to char formation. Finally, the third step is the gasification of the char, which takes place at temperatures above $350^{\circ} \mathrm{C}$. The process finishes when it reaches the temperature of $500{ }^{\circ} \mathrm{C}$ [23].

When air is introduced in the reaction, combustion of char and volatile products takes place, with these products reacting with oxygen. In the gasification reaction, char reacts with carbon dioxide and steam, generating hydrogen gas and carbon monoxide. The high temperatures used in this process bring the reversible water-gas shift reaction into equilibrium [24].

Among these thermal techniques, pyrolysis can be highlighted because of the bio-oil produced. It is an interesting source of biofuels and other high added-value products, such as syn-gas and aromatic compounds, which are described in detail in Section 4.4. The pyrolysis conditions under which bio-oils have been obtained from different biomasses are listed in Table 1.

Table 1. Fiber composition on a dry basis and pyrolysis conditions of biomasses used for bio-oil production.

\begin{tabular}{|c|c|c|c|c|c|c|}
\hline Biomass & CEL (\%) & HEM (\%) & Lignin (\%) & Temperature $\left({ }^{\circ} \mathrm{C}\right)$ & Time (h) & Reference \\
\hline Olive stones & 26.5 & 35.4 & 34.7 & $450-700$ & 2 & [16] \\
\hline Olive tree pruning & 36.6 & 19.7 & 20.8 & $300-650$ & 2 & [14] \\
\hline Corn stover & 34.5 & 33.2 & 21.3 & $350-700$ & 2 & [20] \\
\hline Corn cob & 45.1 & 33.4 & 15.9 & $300-650$ & 2 & [20] \\
\hline Rice straw & 44.5 & 27.2 & 22.7 & $400-700$ & 2 & [20] \\
\hline Sugarcane bagasse & 35.3 & 24.1 & 28.5 & $450-700$ & 2 & [20] \\
\hline Reed canary grass & 39.2 & 21.8 & 8.05 & $300-600$ & 2 & [20] \\
\hline
\end{tabular}

CEL: cellulose; HEM: hemicellulose. 


\section{Pyrolysis}

As mentioned above, pyrolysis is a form of thermal decomposition carried out under an inert atmosphere, i.e., without oxygen.

Bio-oil or pyrolysis oil, which is the liquid phase, consists of water and oxygenated aliphatic and aromatic chemicals [25]. The composition of bio-oils can vary significantly, although they tend to have similar features. The moisture content is usually between 15 and 30\% wt, while the oxygen content ranges between 35 and $40 \% \mathrm{wt}$. Due to the presence of carboxylic acids, bio-oils tends to have low $\mathrm{pH}$ values (2-3). Other components that are usually found in bio-oils are alcohols, esters, aldehydes, ketones, phenols, furans and sugars $[14,25]$.

The chosen conditions of the pyrolysis vary depending on the product to be obtained, resulting in different pyrolysis processes. To favor the formation of carbon, slow pyrolysis processes are used. These are characterized by having a long residence time (from hours to days) as well as a low heating rate. In this type of process, roughly $35 \% \mathrm{wt}$ biochar, $35 \% \mathrm{wt}$ syngas and 30\% wt bio-oil are usually obtained [26]. On the other hand, to increase the production of bio-oil over biochar, fast pyrolysis is more suitable (Figure 1) [27]. In this type of process, the use of a smaller particle size is required in order to obtain uniform heating. Therefore, the use of raw materials with small particle sizes favors the production of bio-oil $[27,28]$.

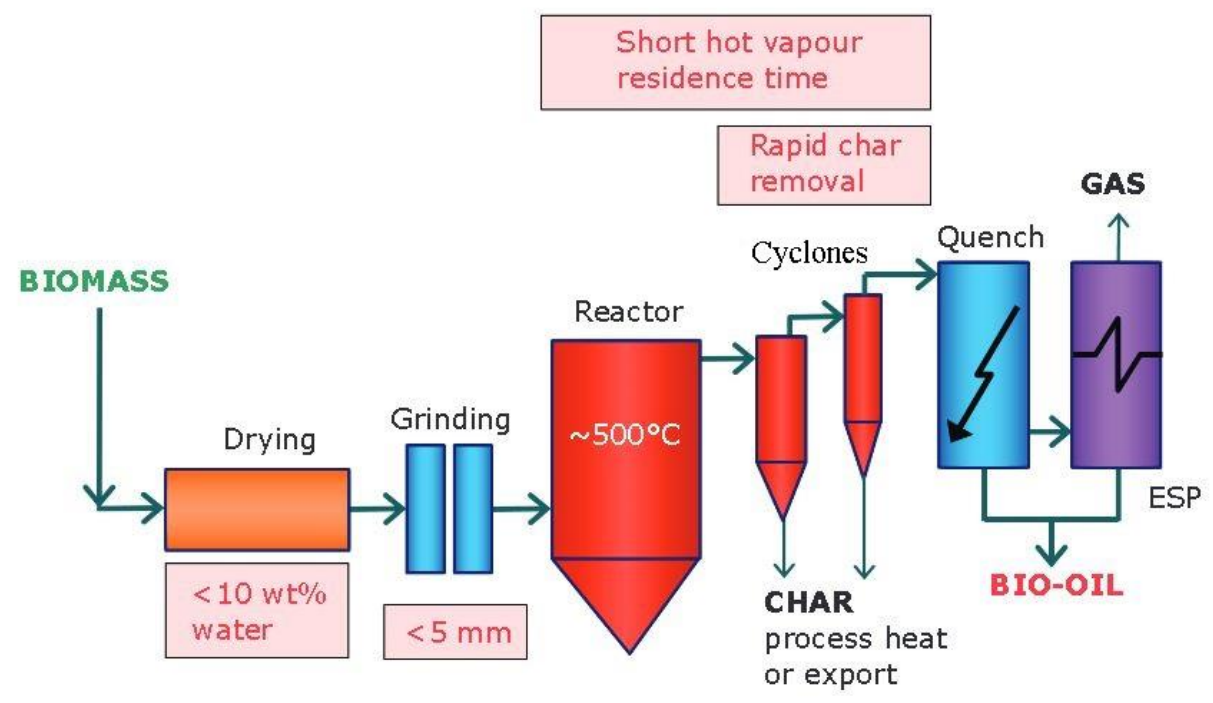

Figure 1. Typical scheme for production of bio-oil via fast pyrolysis [27].

Another essential factor to take into account is the final temperature. A temperature higher than $650{ }^{\circ} \mathrm{C}$ increases the proportion of gaseous product, while heating at low temperatures increases the proportion of biochar. Taking into account these factors, the optimum temperature for the production of bio-oil has to be determined for a specific biomass in order to maximize the formation of the desired product [27].

For instance, in bio-oil production, yields close to $75 \%$ of the weight of the initial biomass (with small amounts of solid carbon and gases) can be obtained. Fast pyrolysis produces bio-oils with lower viscosity and greater miscibility in water than those produced with slow pyrolysis [29].

While it is true that temperature is a factor that plays a key role in the final composition of the products, the temperature ramp, residence time and particle size, together with the heterogeneity of the biomass, mean that pyrolysis reactions have great chemical complexity. Each of the biomass components has characteristic thermal conditions and thus to degrade them they must be subjected to pyrolysis at different temperatures. At the lowest temperatures, in the range of $210-310^{\circ} \mathrm{C}$, hemicellulose is pyrolyzed. Subsequently, cellulose tends to degrade from $300-315{ }^{\circ} \mathrm{C}$, its end point being around $360-380^{\circ} \mathrm{C}$. Finally, 
lignin usually begins its degradation at the same temperature as hemicellulose, over $200^{\circ} \mathrm{C}$, but its pyrolysis range is much higher, since it can be degraded up to $1000{ }^{\circ} \mathrm{C}$ [30].

Furthermore, these pyrolytic processes can be modified through the use of catalysts. For example, some of these catalysts have the objective of reducing the oxygen content of the final bio-oil. Currently, pyrolysis is carried out by thermal depolymerization, together with a subsequent decomposition of the raw material into volatile compounds. However, the deoxygenation reactions that are catalyzed by acid catalysts render a greater formation of hydrocarbon products. This process includes decarboxylation, decarbonylation and dehydration [31].

\section{Applications of Bio-Oils}

Various studies on the uses of bio-oil can be found in the literature from the last 15 years [32-34]. The applications of bio-oil include its direct use [33,34], the production of high-quality biofuels for the automotive industry [35], and its use as a raw material for obtaining high-value chemical compounds, such as aromatic compounds (phenol) [36,37]. With regard to this latter application, one point to note is that some of the organic components of bio-oil are regarded as high added-value products. Bio-oil is a mixture of organic compounds, some of which are fine chemicals with added value. For this reason, the production of organic compounds, such as aromatic chemicals, esters and acids, from bio-oil has gained great importance in recent years [37,38].

On the other hand, the production of certain families of chemical products has also been investigated, since some of them, such as phenols, have plenty of applications. For example, phenols can be used as a raw material to produce binder through crosslinking reactions $[32,39,40]$.

In earlier assays, the pyrolysis of biomass was carried out with the aim of producing a renewable fuel and replacing fossil fuels (gasoline and diesel). Different configurations of pyrolysis and pyrolyzers were proposed for this process. Bubbling, circulation, cone rotation and grinding have been varied in these assays [41]. Some research groups and companies have developed the industrial production of bio-oil. Among them, Red Arrow's Ensyn in Canada and the UPM refinery in Finland can be highlighted.

However, bio-oils also have some characteristics—-such as high acidity, low thermal stability and less calorific power and higher viscosity than diesel-that can cause operation problems when they are used in diesel or gasoline engines [42,43]. To deal with these hindrances, researchers have developed a method that converts bio-oil into a fuel similar to fossil fuels (gasoline and diesel) through the hydrodeoxygenation (HDO) reaction. This is performed to decrease the oxygen content in bio-oil, which increases the calorific value and its thermal stability $[26,35,41]$. Through hydrodeoxygenation problems related to the high oxygen content of bio-oil can be solved [41]. Despite these advantages, the process is still very expensive since external hydrogen is needed in the engine and a metal oxide catalyst is needed for the process, in addition to the potential rapid deactivation of the catalyst due to the formation of coke.

\subsection{Bio-Oil as Fuel for Boilers and Heavy-Duty Engines}

One use of the various kinds of bio-oils is directly burning them together with fossil fuels as furnace and boiler fuels. Furthermore, bio-oil may be more suitable than heavy fossil fuels when it comes to combustion in boilers.

The combustion of bio-oil leads to less pollution by $\mathrm{CO}_{2}, \mathrm{NO}_{\mathrm{x}}$ and $\mathrm{SO}_{\mathrm{x}}$ and thus can result in a reduction of air pollution, avoiding the use of subsequent processes to reduce these pollutants in boilers [44]. From the comparison of the data provided in Table 2, it can be seen that bio-oil has poor fuel properties when compared to fossil fuels. One of the most remarkable differences might be that bio-oil has higher water content compared to heavy fossil fuels (20-30\% wt vs. $0.32 \% \mathrm{wt})$. 
Table 2. Typical fuel properties of bio-oil and fossil fuels [45].

\begin{tabular}{ccccc}
\hline Property & Bio-Oil & Gasoline & Diesel & Heavy Fossil Fuel Oil \\
\hline Density at $15{ }^{\circ} \mathrm{C}\left(\mathrm{kg} / \mathrm{dm}^{3}\right)$ & $1.11-1.13$ & $0.72-0.76$ & $0.78-0.86$ & 0.95 \\
Pour point $\left({ }^{\circ} \mathrm{C}\right)$ & -9 up to -36 & - & -40 & 12 \\
Water content $(\% \mathrm{wt})$ & $20-30$ & - & 0.05 & 0.32 \\
Flash point $\left({ }^{\circ} \mathrm{C}\right)$ & $40-110$ & -43 & 50 & 110 \\
Viscosity $(\mathrm{cSt})$ & $15-40$ at $10{ }^{\circ} \mathrm{C}$ & 0.5 at $20{ }^{\circ} \mathrm{C}$ & 3 at $40{ }^{\circ} \mathrm{C}$ & 130 at $10{ }^{\circ} \mathrm{C}$ \\
Higher heating value $(\mathrm{MJ} / \mathrm{kg})$ & $14-19$ & 45.7 & 47.0 & 42.9 \\
Lower heating value $(\mathrm{MJ} / \mathrm{kg})$ & $13-18$ & 42.9 & 83.0 & 40.6 \\
& $50-60 \% \mathrm{C}$ & $86 \% \mathrm{C}$ & $88.1 \% \mathrm{C}$ \\
Elemental composition $(\% \mathrm{wt})$ & $7-8 \% \mathrm{H}$ & $0 \% \mathrm{C}$ & $12.1 \% \mathrm{H}$ & $0.85 \% \mathrm{H}$ \\
& $\leq 0.5 \% \mathrm{~N}$ & $1 \% \mathrm{H}$ & $0.039 \% \mathrm{~N}$ & $0.5 \% \mathrm{~N}$ \\
& $35-40 \% \mathrm{O}$ & $1.39 \% \mathrm{~S}$ & $0.64 \% \mathrm{O}$ \\
\hline
\end{tabular}

Nevertheless, the higher heating value of bio-oil is similar to other biomasses, such as olive pruning residues, olive stones or olive pomaces, that are currently used in boilers [14].

It can be concluded from Table 2 that the bio-oil produced from pyrolysis cannot be used directly in current burner designs, which are designed for heavy fossil fuels. The primary reason is that, despite having the same flash point, the viscosity of bio-oil is lower than that of heavy fossil fuel oil. Therefore, it is necessary to redesign the current burners in order to use bio-oil as fuel, as the properties of bio-oil are different from those of its fossil analogue. One of the main differences is that the flash point and the pour point are lower for bio-oil compared with heavy fossil fuel, indicating that the storage and pumping components in boilers must be redesigned. In addition, the materials of the components of the boiler that are in contact with the bio-oil (such as the engine and the burner) have to be resistant against corrosion.

To summarize, bio-oil could be used as boiler fuel but the structure and design of current engines would have to be modified for optimal operation.

\subsection{Bio-Oil to Biofuel by Hydrodeoxygenation}

As mentioned earlier, one of the main characteristics of bio-oil is that it contains large amounts of water and heavy aromatic compounds, which results in instability and a low energy content [46-49]. Due to this, its transportation, storage and use in engines are very complicated. A proposed method to treat the product in order to improve its properties is shown in Figure 2 [50].

Hydrodeoxygenation could be used as a process to change the properties of biooil for its use as engine fuel and solve some problems. The process is characterized by operating at high temperature and high pressure, with the aim of reducing the oxygen in the bio-oil [51,52].

The deoxygenated stream consists of hydrocarbons, which can be used as gasoline, naphtha and aviation fuel, or as additives for these fuels, as long as the upgraded bio-oil is fractionated [49]. The main drawback is that the viscosity of biofuel $(1-5 \mathrm{cP})$ is less than that of the fuel oil $(180 \mathrm{cP})$. Due to the influence of this low viscosity, current pumping systems might require some modifications to allow the use of biofuel feeding.

The combustion of these biofuels in automotive engines has been investigated. For instance, the combustion of a hydrotreated bio-oil from pine wood has been assayed in a $20 \mathrm{kWe}$ engine over a period of $40 \mathrm{~h}$ [52]. The engine was able to run without any problems when diesel was replaced with biofuel from bio-oil. By contrast, the operation of the engine was not entirely successful when using $100 \%$ raw bio-oil as feedstock.

This process has yet to be further developed since it requires a catalyst to reduce the formation of coke and increase the rate of hydrodeoxygenation. For this reason, the viability of the industrial-scale catalyzed HDO process for bio-oil production must be verified. The HDO process is hampered due to the formation of coke, which causes the 
rapid deactivation of the catalyst. It has been reported that aromatic compounds and sugars are primarily responsible for the formation of coke [49].

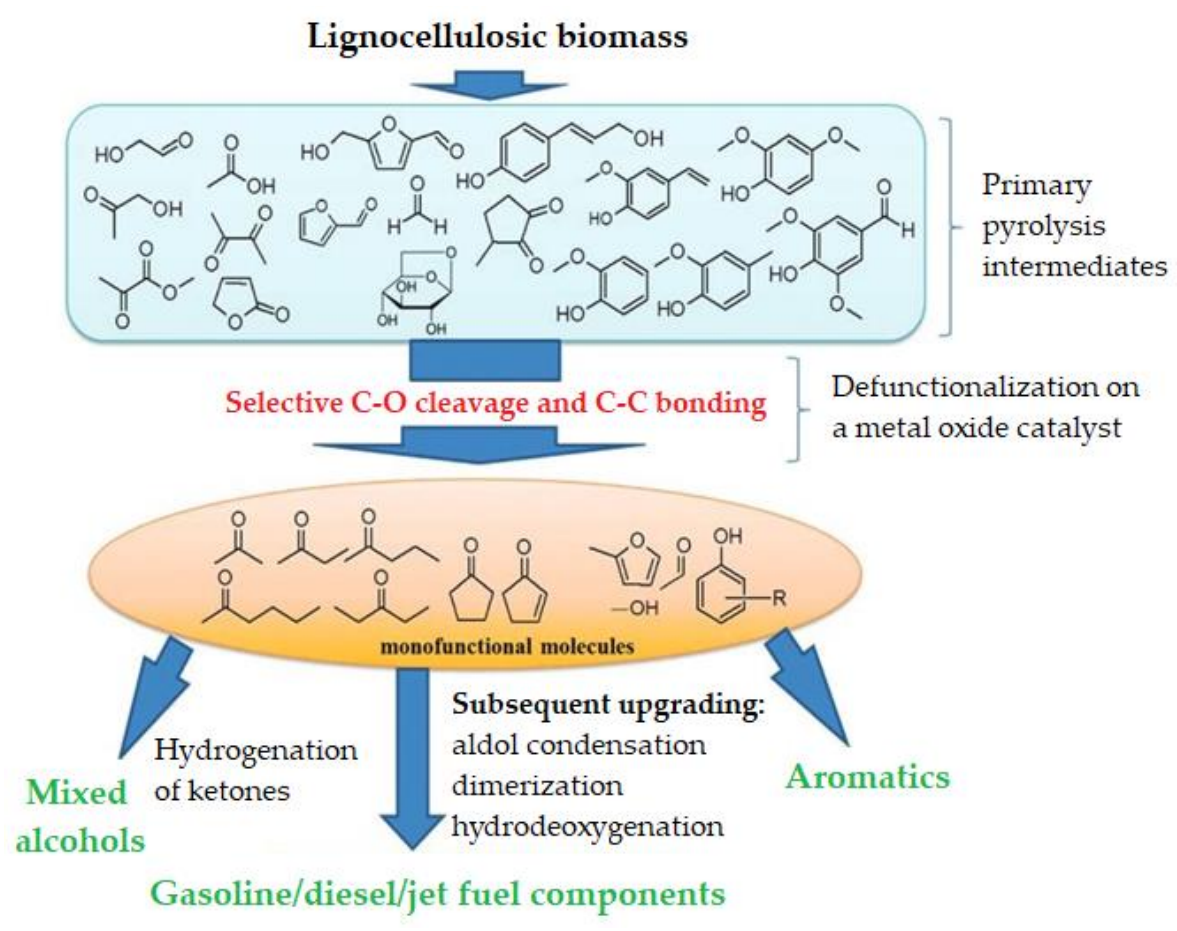

Figure 2. Biofuel production through bio-oil enhancement [50].

\subsection{Bio-Oil to Hydrogen}

Hydrogen is characterized by being a fuel as well as an energy carrier due to its high energy content $(120.7 \mathrm{MJ} / \mathrm{kg}$ ) [53]. Furthermore, the only product or waste generated from hydrogen combustion is water, so $\mathrm{H}_{2}$ combustion does not contribute to the emission of greenhouse gases.

Hydrogen is produced on a large scale mainly through reforming with steam generated from fossil fuels [54]. Due to the poor features of fossil fuels, such as their great atmospheric pollution, and their impeding depletion, researchers are paying attention to the use of biomass as an alternative feedstock to produce hydrogen. The bio-oil steamreforming reaction (Equation 1) can be described as follows [55]:

$$
\mathrm{C}_{\mathrm{n}} \mathrm{H}_{\mathrm{m}} \mathrm{O}_{\mathrm{k}}+(2 \mathrm{n}-\mathrm{k}) \mathrm{H}_{2} \mathrm{O} \Rightarrow \mathrm{nCO}_{2}+\left(2 \mathrm{n}+\frac{\mathrm{m}}{2}-\mathrm{k}\right) \mathrm{H}_{2}
$$

The direct gasification of biomass to produce hydrogen can be performed in a simple process. However, transporting bio-oil over long distances is very expensive due to its low calorific density. One alternative that would reduce the transportation costs could be the use of bio-oil instead of biomass to produce hydrogen, since bio-oil has higher energy density than biomass.

Another advantage of bio-oil is that the hydrogen produced by reforming the bio-oil with steam in the HDO reaction can be used as a reagent in reforming reactions $[53,54,56]$. The main scheme for bio-oil steam reforming is shown in Figure 3. 


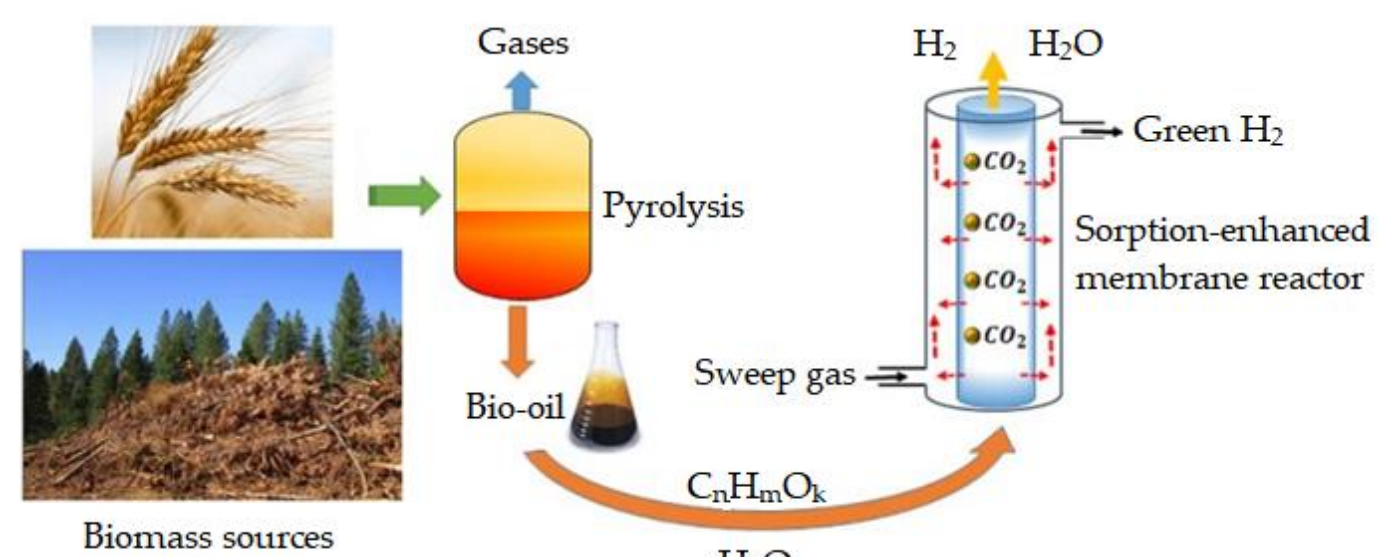

$\mathrm{H}_{2} \mathrm{O}$

Figure 3. Hydrogen production scheme via steam reforming of bio-oil [55].

Different types of reactors have been tested with regard to the reforming reaction of bio-oil with steam. The design of the reactor plays a key role in avoiding the formation of coke in the previously described reaction, since the coke production reaction is very fast [53]. For instance, the first reactors tested in the reforming reaction were fixed-bed and fluidized-bed reactors. The durability of fluidized-bed reactors is greater than that of fixed-bed ones, since the coke formed during the above-described process can be gasified.

The largest formations of coke are generally observed in the bio-oil injection line and in the reactor inlet section. To overcome this problem, some researchers have used a nozzle to feed bio-oil into the reactor, which increases the feeding rate [57]. These researchers found that the use of a nozzle, under the assayed conditions, prevented the formation of coke for $35 \mathrm{~h}$. Furthermore, the injection point was located at a considerable distance from the catalytic bed in order to keep the inlet temperature as low as possible, thus minimizing coke production at the nozzle outlet.

Furthermore, to achieve high reaction rates and increase hydrogen selectivity, catalysts have been used in steam reforming. This also minimizes the formation of coke. The main catalysts assayed so far have been those based on Ni doped with transition metals [53]. Noble metals, such as $\mathrm{Pt}$ and $\mathrm{Ru}$, apart from being very selective and stable over time in a stream, are less prone to coke deposition on their catalytic surface. Nevertheless, their high prices prevent their use at a large scale.

\subsection{Bio-Oil to High-Value Chemicals}

Currently, most industrial chemicals as well as those used in daily life are obtained from fossil fuel feedstocks. Nevertheless, research on the production and separation of chemicals from bio-oil has been stimulated in the last few years [58]. Different methods have been applied to separate chemicals from bio-oil. Among them, the two outstanding and most widely used methods are the distillation and solvent extraction techniques.

\subsubsection{Distillation of Bio-Oil}

The high added-value chemicals of bio-oil can be separated by distillation at high temperatures and atmospheric pressure [33]. Due to high concentrations of reactive organic oxygen compounds, such as aromatics, ketones and aldehydes, the polymerization of these compounds takes place at these high distillation temperatures. Therefore, vacuum distillation is recommended in order to decrease the distillation temperature, and avoid these undesirable reactions.

Furthermore, it has been proved that separation efficiency is improved under vacuum distillation and that this technique can separate smaller molecules, such as various types of acids (acetic and formic), as well as hydroxyacetone [59]. 


\subsubsection{Solvent Extraction}

Various solvents for the extraction of chemicals from bio-oil have been assayed, including alkaline solutions, ketones, ethers, water, super-critical $\mathrm{CO}_{2}$, ethyl acetate, toluene and n-hexane $[60,61]$.

In one method, phenols were extracted from a bio-oil produced from the pyrolysis of sawdust, which was carried out by means of a solvent [60]. The phenols were extracted by adding ethyl ether and 10\% wt caustic soda, finally obtaining sodium phenoxide. Furthermore, phenols have also been extracted with hydrochloric acid. Other researchers have carried out the extraction of different organic compounds from the bio-oil of forest residues by adding n-hexane, water and dichloromethane [62].

\subsection{Conversion of Bio-Oil to Carbonaceous Materials}

The applications of carbonaceous materials, which are usually produced from coal or biomass, cover a wide range, especially at the industrial scale [63]. The production of these carbonaceous materials from bio-oil is an attractive proposition in light of the fact that they have a positive impact on the environment due to their sustainability as raw materials. Furthermore, biomass generally has low or zero sulphur content and nitrogen content has been reported to be much lower than that in coal. The porous structure of activated carbon is also responsible for its low mechanical resistance.

In order to increase the mechanical resistance of carbonaceous materials made from biomass, a methodology has been developed for their manufacture from bio-oil and biochar [63]. When the pores of biochar are filled with the solids resulting from the polymerization of the bio-oil, the above-described mechanical resistance increases.

From the studies available in the literature on the production of carbonaceous materials from bio-oil, it can be concluded that the technology has to be improved and developed through further investigation in order to identify feasible pathways and their mechanisms. This could provide an overview of the possibilities for the production of specific carbonaceous materials under the most suitable conditions.

\subsection{Electrodes}

Pitch is regarded as one of the most abundant raw materials available to obtain electrodes. In industry, the tar produced from coal is used as pitch. Nevertheless, in recent years a part of the tar produced from the pyrolysis of biomass - called biopitch-has been investigated, which could replace the tar derived from coal [64]. One advantage is that its oxygen content is higher than that of pitch $(20 \% \mathrm{wt}$ instead of $2 \% \mathrm{wt})$. This higher content can improve the softening point during heating, mainly due to water vapor and the presence of some light compounds in the material during heating.

Furthermore, the higher oxygen content is translated into an increase in the reactivity of the pitch, with the ultimate goal of polymerization during heating [64]. Furthermore, the production of solid products from bio-oil is favored due to the high oxygen content.

\subsection{Bio-Oil in Asphalt}

The use of bio-oil as a source of binder for asphalt could overcome the uncertainty in the supply of petroleum-based binders [65]. Bio-oil from the pyrolysis of biomass can be used as a binder in asphalt, not only because it is renewable, but also due to its low levels of heterogeneous atoms, such as sulphur (almost nil) and nitrogen $(0.5 \% \mathrm{wt})[26,41,42,44]$, as well as the presence of high levels of phenols, such as phenolic monomers and pyrolytic lignin in the bio-binder structure, which are derived from the degradation of lignin to some extent. These compounds account for the potential of the use of bio-oil in asphalt [66]. The rheological properties of bio-oil as a bio-binder have been compared with those of petroleum resources [67]. The authors of one study pyrolyzed oak wood to obtain bio-oil and studied the specifications of this bio-binder and a mixture of the same with polyethylene at 2 and $4 \% \mathrm{wt}$, added to control the viscosity in the binder derived from coal. 
The authors found that both the bio-binder and its mixture with polyethylene had great potential for substituting asphalt binders derived from coal [67].

\subsection{Pesticides}

Another example of the use of bio-oil is the production of pyroligneous acid, also known as wood vinegar, which is obtained from the slow pyrolysis liquid fraction obtained as a byproduct of charcoal production. It is one of the most valuable products of the pyrolysis of biomass and has biocide properties that make the bio-oil containing it a potential pesticide. For instance, it has been reported that wood vinegar obtained from the pyrolysis of bamboo is effective in controlling fungi at concentrations between 0.1 and $1 \%$ wt [68]. This wood vinegar includes acetic acid, one of the organics acids produced from pyrolysis. This acid can account for around $15 \%$ wt in wood bio-oil.

\subsection{Polyurethane Foams Formation}

Polyurethane (PU) has many of different uses in industry, including as feedstock for the production of insulation materials, medicine and furniture [69]. Normally, it is produced from fossil fuel resources through the reaction between isocyanates and polyols.

Recently, some researchers have investigated how to produce PU from bio-oil, looking at the viability and profitability of the process [68]. Biopolyol was extracted from bio-oil using an organic solvent (ethyl acetate), which was mixed with bio-oil at the same ratio. The authors of this study claimed to have obtained PU foam with some properties similar to those of commercial PU through the use of condensation reactions among biopolyol, polymethylene polyphenyl isocyanate, polymeric diphenyl methane diisocyanate and some additives.

\subsection{Plastics}

One of the less well-known uses of fossil fuels, from within the great variety of their uses, is the production of plastics. Due to their low degradation kinetics, the huge amount of plastics produced in the world is accumulated in the environment, generating a huge environmental problem $[69,70]$. Furthermore, the production of additives causes environmental problems, such as the production of toxins (phthalates and plasticizers), during the process of plastic de-composition. As a result, researchers have paid attention to the production of biodegradable plastics over the last few decades [70-72]. Fractionation of bio-oil has been carried out successfully, giving rise to various chemical products such as ethanol, xylose, acetic acid, ethylene and others. Some of these can be used as monomers for the production of different plastics [70]. However, their high price, lower mechanical properties and low-quality appearance narrow their potential for production at a large scale.

\subsection{Biodiesel}

As mentioned earlier, bio-oils produced from lignocellulose residues by fast pyrolysis or catalytic fast pyrolysis are regarded as suitable raw materials to produce renewable diesel [73].

In order to stabilize the hydrotreated bio-oil, butane and other light compounds are removed with a lights removal column [74]. Later, the stable bio-oil stream is separated into light and heavy fractions. The heavy fraction (boiling point above $350{ }^{\circ} \mathrm{C}$ ) is then sent to a hydrocracker to completely convert the bio-oil into gasoline and diesel blend components. The main process might occur as shown in Figure 4. 


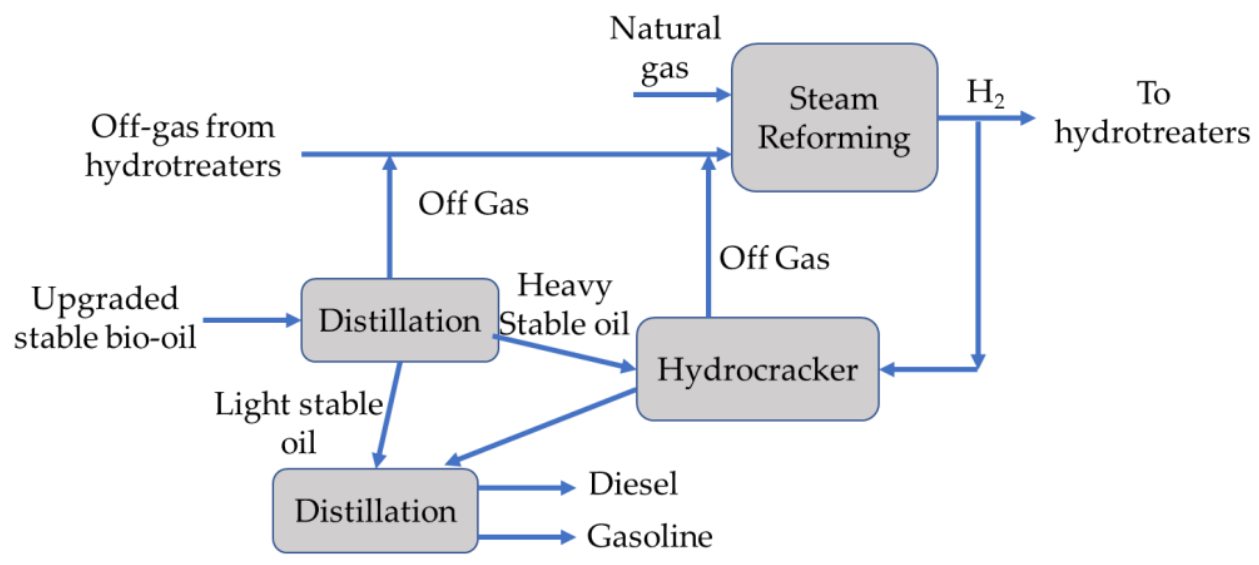

Figure 4. Block diagram for hydrocracking and product separation [74].

The final product is a mixture of liquids spanning the gasoline and diesel range and some gaseous byproducts. The gasoline and diesel products can be separated by distillation. While biodiesel from transesterification of triglycerides from vegetal oils or animal fats is composed of methyl (or ethyl) esters, biodiesel from bio-oil has a similar composition to that of fossil diesel (hydrocarbons, mainly paraffins, aromatics and naphthenes). Methylester biodiesel is commercially found mixed with commercial diesel in varying percentages ranging from $5 \%$ to $30 \%$, although $100 \%$ methyl-ester biodiesel can also be found to a lesser extent. As a result, the presence of biodiesel from the transesterification of triglycerides in the fuel affects its physical and chemical properties. On the contrary, biodiesel obtained from hydrocracking of bio-oil is regarded as suitable for blending with petroleum diesel [74]. The yield of fuel products based on $100 \%$ renewable raw material has been reported to be approximately $65 \%$ wt [74]. Furthermore, the carbon balance is shown in Table 3 . As can be seen, researchers achieved a 55\% wt conversion of the carbon in the combined feed (biomass plus natural gas) into fuel products.

Table 3. Carbon balance of product fuel from wood [74].

\begin{tabular}{lll}
\hline \multirow{2}{*}{ Raw material } & Biomass & $88 \% \mathrm{wt}$ \\
& Natural gas & $12 \% \mathrm{wt}$ \\
\hline \multirow{2}{*}{ Fuel products } & Gasoline pool & $23 \% \mathrm{wt}$ \\
& Diesel pool & $32 \% \mathrm{wt}$ \\
\hline \multirow{2}{*}{ Waste products } & Pyrolysis unit exhaust & $23 \% \mathrm{wt}$ \\
& Upgrading wastewater & $0 \% \mathrm{wt}$ \\
& Upgrading heaters exhaust & $2 \% \mathrm{wt}$ \\
\hline
\end{tabular}

Another strategy might be burning a blend of bio-oil and diesel in an oil-fired furnace [75]. Although using bio-oil to replace fossil fuels has limitations due to undesirable properties of bio-oil, such as high water, acidity and oxygen contents, low heating value, and so on, a low blend ratio of bio-oil used to substitute petroleum-derived oil has advantages. For instance, it can be easily combusted in furnaces without any modifications. Thus, bio-oil blended with $5 \%(\mathrm{v} / \mathrm{v})$ diesel achieved a stable combustion, emitting less $\mathrm{CO}_{2}, \mathrm{NO}$, $\mathrm{SO}_{2}$ and $\mathrm{CO}$ than pure diesel. Furthermore, a study on the life cycle assessment of the production of bio-fuels from bio-oil showed that the life cycle assessment for diesel produced by fast pyrolysis of forest residues and subsequent hydrotreating and hydrocracking indicated greenhouse gases emissions of $0.142 \mathrm{~kg} \mathrm{CO}_{2}$-eq per $\mathrm{km}$ and a net energy value of $1.00 \mathrm{MJ}$ per km, which are lower than those obtained for fossil fuels. [76]. 


\section{Conclusions}

Due to the interesting features of bio-oil, such as higher energetic density and less pollution compared with fuels from fossil feedstocks, it is being widely used nowadays at both laboratory and industrial scales.

Bio-oil is a firm alternative to fossil fuels feedstocks with a wide range of applications but, in order to achieve a better quality process, further investigations have to be carried out to enhance its properties. However, it is also essential to highlight the important role that bio-oil could play nowadays in global industry, with fossil fuels getting closer to depletion every day.

In this context, the most feasible way to improve and use bio-oil might be hydrotreatment, which can transform waste such as residual forestry biomass into a byproduct with real applications. Thus, the renewable fuels obtained by hydrotreatment of bio-oil can be used for direct combustion or in biorefineries.

However, other potential uses of bio-oil, such as in the production of bioplastics, are less attractive since their production costs are higher than those of fossil fuels and, specifically for bioplastics, their mechanical properties and the quality of appearance are worse. However, the production of asphalt from bio-oil is attractive due to its lack of sulphur content, but this has to be further developed in the future.

Author Contributions: F.J.S.-B., P.Á.-M., J.F.G.-M. are equally participated in the writing of this review paper. F.J.S.-B., P.Á.-M., J.F.G.-M. have read and agreed to the published version of the manuscript. All authors have read and agreed to the published version of the manuscript.

Funding: This review paper is within the LIFE 13-Bioseville ENV/1113 project, funded by the European Union.

Institutional Review Board Statement: Not applicable.

Informed Consent Statement: Not applicable.

Conflicts of Interest: The authors declare no conflict of interest.

\section{References}

1. Bhatia, S.K.; Bhatia, R.K.; Jeon, J.M.; Pugazhendhi, A.; Awasthi, M.K.; Kumar, D.; Kumar, G.; Yoon, J.J.; Yang, Y.H. An overview on advancements in biobased transesterification methods for biodiesel production: Oil resources, extraction, biocatalysts, and process intensification technologies. Fuel 2021, 285, 119117. [CrossRef]

2. García Martín, J.F. Recent Developments in Jatropha Research; Nova Science Publishers, Inc.: Hauppauge, NY, USA, 2021; ISBN 978-1-53619-132-5.

3. Álvarez-Mateos, P.; García-Martín, J.F.; Guerrero-Vacas, F.J.; Naranjo-Calderón, C.; Barrios, C.C.; Pérez Camino, M.d.C. Valorization of a high-acidity residual oil generated in the waste cooking oils recycling industries. Grasas Aceites 2019, 70 , e335. [CrossRef]

4. Kumar, H.; Sarma, A.K.; Kumar, P. A comprehensive review on preparation, characterization, and combustion characteristics of microemulsion based hybrid biofuels. Renew. Sustain. Energy Rev. 2020, 117, 109498. [CrossRef]

5. Singh, D.; Sharma, D.; Soni, S.L.; Inda, C.S.; Sharma, S.; Sharma, P.K.; Jhalani, A. A comprehensive review of physicochemical properties, production process, performance and emissions characteristics of 2nd generation biodiesel feedstock: Jatropha curcas. Fuel 2021, 285, 119110. [CrossRef]

6. García-Martín, J.F.; Barrios, C.C.; Alés-Álvarez, F.J.; Dominguez-Sáez, A.; Alvarez-Mateos, P. Biodiesel production from waste cooking oil in an oscillatory flow reactor. Performance as a fuel on a TDI diesel engine. Renew. Energy 2018, 125, 546-556. [CrossRef]

7. Hassan, A.A.; Smith, J.D. Investigation of microwave-assisted transesterification reactor of waste cooking oil. Renew. Energy 2020, 162, 1735-1746. [CrossRef]

8. Carbajal, E.M.T.; Hernández, E.M.; Linares, L.F.; Maldonado, E.N.; Ballesteros, R.L. Techno-economic analysis of Scenedesmus dimorphus microalgae biorefinery scenarios for biodiesel production and glycerol valorization. Bioresour. Technol. Rep. 2020, 12, 100605. [CrossRef]

9. Athar, M.; Zaidi, S. A review of the feedstocks, catalysts, and intensification techniques for sustainable biodiesel production. J. Environ. Chem. Eng. 2020, 8, 104523. [CrossRef]

10. Mondal, B.; Jana, A.K. Techno-economic feasibility of reactive distillation for biodiesel production from algal oil: Comparing with a conventional multiunit system. Ind. Eng. Chem. Res. 2019, 58, 12028-12040. [CrossRef] 
11. Shuai, W.; Das, R.K.; Naghdi, M.; Brar, S.K.; Verma, M. A review on the important aspects of lipase immobilization on nanomaterials. Biotechnol. Appl. Biochem. 2017, 64, 496-508. [CrossRef]

12. Bhatia, S.K.; Gurav, R.; Choi, T.R.; Kim, H.J.; Yang, S.Y.; Song, H.S.; Park, J.Y.; Park, Y.L.; Han, Y.H.; Choi, Y.K.; et al. Conversion of waste cooking oil into biodiesel using heterogenous catalyst derived from cork biochar. Bioresour. Technol. 2020, $302,122872$. [CrossRef]

13. Zhang, Y.H.P. Reviving the carbohydrate economy via multi-product lignocellulose biorefineries. J. Ind. Microbiol. Biotechnol. 2008, 35, 367-375. [CrossRef]

14. García Martín, J.F.; Cuevas, M.; Feng, C.H.; Álvarez Mateos, P.; Torres García, M.; Sánchez, S. Energetic valorisation of olive biomass: Olive-tree pruning, olive stones and pomaces. Processes 2020, 8, 511. [CrossRef]

15. Cuevas, M.; Saleh, M.; García-Martín, J.F.; Sánchez, S. Acid and enzymatic fractionation of olive stones for ethanol production using Pachysolen tannophilus. Processes 2020, 8, 195. [CrossRef]

16. Cuevas, M.; García Martín, J.F.; Bravo, V. Ethanol production from olive stones through liquid hot water pre-treatment, enzymatic hydrolysis and fermentation. Influence of enzyme loading, and pre-treatment temperature and time. Fermentation 2021, 7, 25 [CrossRef]

17. Zhang, J.; Cai, D.; Qin, Y.; Liu, D.; Zhao, X. High value-added monomer chemicals and functional bio-based materials derived from polymeric components of lignocellulose by organosolv fractionation. J. Chem. Inf. Model. 2019, 53, 1689-1699. [CrossRef]

18. García Martín, J.F.; Cuevas, M.; Bravo, V.; Sánchez, S. Ethanol production from olive prunings by autohydrolysis and fermentation with Candida tropicalis. Renew. Energy 2010, 35, 1602-1608. [CrossRef]

19. Zhu, H.; Luo, W.; Ciesielski, P.N.; Fang, Z.; Zhu, J.Y.; Henriksson, G.; Himmel, M.E.; Hu, L. Wood- derived materials for green electronics, biological devices, and energy applications. Chem. Rev. 2016, 116, 9305-9374. [CrossRef] [PubMed]

20. Tanger, P.; Field, J.L.; Jahn, C.E.; DeFoort, M.W.; Leach, J.E. Biomass for thermochemical conversion: Targets and challenges. Front. Plant Sci. 2013, 4, 1-20. [CrossRef]

21. van der Stelt, M.J.C.; Gerhauser, H.; Kiel, J.H.A.; Ptasinski, K.J. Biomass upgrading by torrefaction for the production of biofuels: A review. Biomass Bioenergy 2011, 35, 3748-3762. [CrossRef]

22. Reed, T.B. Combustion, pyrolysis, gasification and liquefaction of biomass. In Proceedings of the Energy from Biomass Conference, Brighton, UK, 4-7 November 1980.

23. Najeeb, K.; Dustin, D.; Xianglan, B.; Kwang, H.K.; Robert, C.B. Pyrolytic sugars from cellulosic biomass. ChemPubSoc Eur. 2012, 5, 2228-2236.

24. Kirubakaran, V.; Sivaramakrishnan, V.; Nalini, R.; Sekar, T.; Premalatha, M.; Subramanian, P. A review on gasification of biomass Renew. Sustain. Energy Rev. 2009, 13, 179-186. [CrossRef]

25. Yaman, S. Pyrolysis of biomass to produce fuels and chemical feedstocks. Energy Convers. Manag. 2004, 45, 651-671. [CrossRef]

26. Kan, T.; Strezov, V.; Evans, T.J. Lignocellulosic biomass pyrolysis: A review of product properties and effects of pyrolysis parameters. Renew. Sustain. Energy Rev. 2016, 57, 1126-1140. [CrossRef]

27. Bridgwater, T. Challenges and opportunities in fast pyrolysis of biomass: Part II. Johns. Matthey Technol. Rev. 2018, 62, 150-160. [CrossRef]

28. Onay, O.; Kockar, O.M. Slow, fast and flash pyrolysis of rapeseed. Renew. Energy 2003, 28, 2417-2433. [CrossRef]

29. Bridgwater, A.V. Catalysis in thermal biomass conversion. Appl. Catal. A Gen. 1994, 116, 5-47. [CrossRef]

30. Zhou, H.; Long, Y.; Meng, A.; Li, Q.; Zhang, Y. The pyrolysis simulation of five biomass species by hemi-cellulose, cellulose and lignin based on thermogravimetric curves. Thermochim. Acta 2013, 566, 36-43. [CrossRef]

31. Wang, K.; Kim, K.H.; Brown, R.C. Catalytic pyrolysis of individual components of lignocellulosic biomass. Green Chem. 2014, 16, 727-735. [CrossRef]

32. Mirkouei, A.; Haapala, K.R.; Sessions, J.; Murthy, G.S. A review and future directions in techno-economic modeling and optimization of upstream forest biomass to bio-oil supply chains. Renew. Sustain. Energy Rev. 2017, 67, 15-35. [CrossRef]

33. Czernik, S.; Bridgwater, A.V. Overview of applications of biomass fast pyrolysis oil. Energy Fuels 2004, 18, 590-598. [CrossRef]

34. Brammer, J.G.; Lauer, M.; Bridgwater, A.V. Opportunities for biomass-derived "bio-oil” in European heat and power markets. Energy Policy 2006, 34, 2871-2880. [CrossRef]

35. Xu, X.; Li, Z.; Sun, Y.; Jiang, E.; Huang, L. High- quality fuel from the upgrading of heavy bio-oil by the combination of ultrasonic treatment and mutual solvent. Energy Fuels 2018, 32, 3477-3487. [CrossRef]

36. Rashid, U.; Nizami, A.-S.; Rehan, M. Waste biomass utilization for value-added green products. Curr. Org. Chem. 2019, 23, 1497-1498. [CrossRef]

37. Wang, Y.; Li, X.; Mourant, D.; Gunawan, R.; Zhang, S.; Li, C.Z. Formation of aromatic structures during the pyrolysis of bio-oil. Energy Fuels 2012, 26, 241-247. [CrossRef]

38. Rehan, M.; Nizami, A.S.; Rashid, U.; Naqvi, M.R. Editorial: Waste biorefineries: Future energy, green products and waste treatment. Front. Energy Res. 2019, 7, 3-5. [CrossRef]

39. Maneffa, A.; Priecel, P.; Lopez-Sanchez, J.A. Biomass-derived renewable aromatics: Selective routes and outlook for p-xylene commercialisation. ChemSusChem 2016, 9, 2736-2748. [CrossRef]

40. Vélez, D.C.P.; Magalhães, W.L.E.; Capobianco, G. Carbon fiber from fast pyrolysis bio-oil. Sci. Technol. Mater. 2018, 30, 16-22. [CrossRef] 
41. $\mathrm{Hu}, \mathrm{X}$; Gholizadeh, M. Biomass pyrolysis: A review of the process development and challenges from initial researches up to the commercialisation stage. J. Energy Chem. 2019, 39, 109-143. [CrossRef]

42. Hughey, C.A.; Hendrickson, C.L.; Rodgers, R.P.; Marshall, A.G. Elemental composition analysis of processed and unprocessed diesel fuel by electrospray ionization fourier transform ion cyclotron resonance mass spectrometry. Energy Fuels 2001, 15, 1186-1193. [CrossRef]

43. Gholizadeh, M.; Gunawan, R.; Hu, X.; Mercader, F.D.M.; Westerhof, R.; Chaitwat, W.; Hasan, M.M.; Mourant, D.; Li, C.Z. Effects of temperature on the hydrotreatment behaviour of pyrolysis bio-oil and coke formation in a continuous hydrotreatment reactor. Fuel Process. Technol. 2016, 148, 175-183. [CrossRef]

44. Hou, S.S.; Huang, W.C.; Rizal, F.M.; Lin, T.H. Co-firing of fast pyrolysis bio-oil and heavy fuel oil in a 300-kW th furnace. Appl. Sci. 2016, 6, 326. [CrossRef]

45. Hu, X.; Gholizadeh, M. Progress of the applications of bio-oil. Renew. Sustain. Energy Rev. 2020, 134, 110124. [CrossRef]

46. Lehto, J.; Oasmaa, A.; Solantausta, Y.; Kytö, M.; Chiaramonti, D. Review of fuel oil quality and combustion of fast pyrolysis bio-oils from lignocellulosic biomass. Appl. Energy 2014, 116, 178-190. [CrossRef]

47. Chiaramonti, D.; Prussi, M.; Buffi, M.; Tacconi, D. Sustainable bio kerosene: Process routes and industrial demonstration activities in aviation biofuels. Appl. Energy 2014, 136, 767-774. [CrossRef]

48. Chiaramonti, D.; Bonini, M.; Fratini, E.; Tondi, G.; Gartner, K.; Bridgwater, A.V. Development of emulsions from biomass pyrolysis liquid and diesel and their use in engines-Part 2: Tests in diesel engines. Fuel Energy Abstr. 2004, 45, 48. [CrossRef]

49. Han, Y.; Gholizadeh, M.; Tran, C.C.; Kaliaguine, S.; Li, C.Z.; Olarte, M.; Garcia-Perez, M. Hydrotreatment of pyrolysis bio-oil: A review. Fuel Process. Technol. 2019, 195, 106140. [CrossRef]

50. Mante, O.D.; Rodriguez, J.A.; Senanayake, S.D.; Babu, S.P. Catalytic conversion of biomass pyrolysis vapors into hydrocarbon fuel precursors. Green Chem. 2015, 17, 2362-2368. [CrossRef]

51. Wildschut, J. Pyrolysis oil upgrading to transportation fuels by catalytic hydrotreatment. Ph.D. Thesis, University of Groningen, Groningen, The Netherlands, 2009.

52. Van De Beld, B.; Holle, E.; Florijn, J. The use of pyrolysis oil and pyrolysis oil derived fuels in diesel engines for CHP applications. Appl. Energy 2013, 102, 190-197. [CrossRef]

53. Kumar, A.; Chakraborty, J.P.; Singh, R. Bio-oil: The future of hydrogen generation. Biofuels 2017, 8, 663-674. [CrossRef]

54. Kirtay, E. Recent advances in production of hydrogen from biomass. Energy Convers. Manag. 2011, 52, 1778-1789. [CrossRef]

55. Soria, M.A.; Barros, D.; Madeira, L.M. Hydrogen production through steam reforming of bio-oils derived from biomass pyrolysis: Thermodynamic analysis including in situ $\mathrm{CO}_{2}$ and/or $\mathrm{H}_{2}$ separation. Fuel 2019, 244, 184-195. [CrossRef]

56. Zhang, L.; Hu, X.; Hu, K.; Hu, C.; Zhang, Z.; Liu, Q.; Hu, S.; Xiang, J.; Wang, Y.; Zhang, S. Progress in the reforming of bio-oil derived carboxylic acids for hydrogen generation. J. Power Sources 2018, 403, 137-156. [CrossRef]

57. Basagiannis, A.C.; Verykios, X.E. Steam reforming of the aqueous fraction of bio-oil over structured $\mathrm{Ru} / \mathrm{MgO} / \mathrm{Al}_{2} \mathrm{O}_{3}$ catalysts. Catal. Today 2007, 127, 256-264. [CrossRef]

58. Hu, X.; Zhang, Z.; Gholizadeh, M.; Zhang, S.; Lam, C.H.; Xiong, Z.; Wang, Y. Coke formation during thermal treatment of bio-oil. Energy Fuels 2020, 34, 7863-7914. [CrossRef]

59. Zhang, X.S.; Yang, G.X.; Jiang, H.; Liu, W.J.; Ding, H.S. Mass production of chemicals from biomass-derived oil by directly atmospheric distillation coupled with co-pyrolysis. Sci. Rep. 2013, 3, 1-7. [CrossRef]

60. Shah, Z.; CV, R.; AC, M.; DS, R. Separation of Phenol from Bio-oil produced from pyrolysis of agricultural wastes. Mod. Chem. Appl. 2017, 5, 1000199. [CrossRef]

61. Wang, J.; Cui, H.; Wei, S.; Zhuo, S.; Wang, L.; Li, Z.; Yi, W. Separation of biomass pyrolysis oil by supercritical $\mathrm{CO}_{2}$ extraction. Smart Grid Renew. Energy 2010, 01, 98-107. [CrossRef]

62. Oasmaa, A.; Kuoppala, E.; Solantausta, Y. Fast pyrolysis of forestry residue. 2. Physicochemical composition of product liquid. Energy Fuels 2003, 17, 433-443. [CrossRef]

63. Hu, X.; Nango, K.; Bao, L.; Li, T.; Mahmudul Hasan, M.D.; Li, C.Z. High yields of solid carbonaceous materials from biomass. Green Chem. 2019, 21, 1128-1140. [CrossRef]

64. Rocha, J.D.; Coutinho, A.R.; Luengo, C.A. Biopitch produced from eucalyptus wood pyrolysis liquids as a renewable binder for carbon electrode manufacture. Braz. J. Chem. Eng. 2002, 19, 127-132. [CrossRef]

65. Aziz, M.M.A.; Rahman, M.T.; Hainin, M.R.; Bakar, W.A. An overview on alternative binders for flexible pavement. Constr. Build. Mater. 2015, 84, 315-319. [CrossRef]

66. Wang, H.; Ma, Z.; Chen, X.; Hasan, M.R.M. Preparation process of bio-oil and bio-asphalt, their performance, and the application of bio-asphalt: A comprehensive review. J. Traffic Transp. Eng. 2020, 7, 137-151. [CrossRef]

67. Raouf, M.A.; Williams, R.C. Temperature and shear susceptibility of a nonpetroleum binder as a pavement material. Transp. Res. Rec. 2010, 2180, 9-18. [CrossRef]

68. Tiilikkala, K.; Fagernäs, L.; Tiilikkala, J. History and use of wood pyrolysis liquids as biocide and plant protection product. Open Agric. J. 2014, 4, 111-118. [CrossRef]

69. Wu, J.; Wang, Y.; Wan, Y.; Lei, H.; Yu, F.; Liu, Y.; Chen, P.; Yang, L.; Ruan, R. Processing and properties of rigid polyurethane foams based on bio-oils from microwave-assisted pyrolysis of corn stover. Int. J. Agric. Biol. Eng. 2009, 2, 40-50. [CrossRef]

70. Laycock, B.; Nikolić, M.; Colwell, J.M.; Gauthier, E.; Halley, P.; Bottle, S.; George, G. Lifetime prediction of biodegradable polymers. Prog. Polym. Sci. 2017, 71, 144-189. [CrossRef] 
71. Asghari, F.; Samiei, M.; Adibkia, K.; Akbarzadeh, A.; Davaran, S. Biodegradable and biocompatible polymers for tissue engineering application: A review. Artif. Cells Nanomed. Biotechnol. 2017, 45, 185-192. [CrossRef]

72. Kargarzadeh, H.; Huang, J.; Lin, N.; Ahmad, I.; Mariano, M.; Dufresne, A.; Thomas, S.; Gałeski, A. Recent developments in nanocellulose-based biodegradable polymers, thermoplastic polymers, and porous nanocomposites. Prog. Polym. Sci. 2018, 87, 197-227. [CrossRef]

73. Spatari, S.; Larnaudie, V.; Mannoh, I.; Wheeler, M.C.; Macken, N.A.; Mullen, C.A.; Boateng, A.A. Environmental, exergetic and economic tradeoffs of catalytic- and fast pyrolysis-to-renewable diesel. Renew. Energy 2020, 162, 371-380. [CrossRef]

74. Jones, S.; Valkenburg, C.; Walton, C. Production of Gasoline and Diesel from Biomass via Fast Pyrolysis, Hydrotreating and Hydrocracking: A Design Case; Pacific Northwest National Lab.: Springfield, MO, USA, 2009.

75. Hou, S.S.; Huang, W.C.; Lin, T.H. Co-combustion of fast pyrolysis bio-oil derived from coffee bean residue and diesel in an oil-fired furnace. Appl. Sci. 2017, 7, 1085. [CrossRef]

76. Hsu, D. Life cycle assessment of gasoline and diesel produced via fast pyrolysis and hydroprocessing. Contract 2011, 303, 275-3000. [CrossRef] 